\title{
PHOSPHORUS ACCUMULATION AND POLLUTION POTENTIAL IN A HAPLUDULT FERTILIZED WITH PIG MANURE ${ }^{(1)}$
}

\author{
Renato Guardini $^{(2)}$, Jucinei José Comin ${ }^{(3)}$, Danilo Rheinheimer dos Santos ${ }^{(4)}$, Luciano \\ Colpo Gatiboni ${ }^{(5)}$, Tales Tiecher ${ }^{(6)}$, Djalma Schmitt ${ }^{(7)}$, Marcos Antônio Bender ${ }^{(8)}$, Paulo \\ Belli Filho $^{(9)}$, Paulo Amando Victoria de Oliveira ${ }^{(10)}$ \& Gustavo Brunetto ${ }^{(11)}$
}

\begin{abstract}
SUMMARY
Successive applications of pig litter to the soil surface can increase the phosphorus $(P)$ content and alter its adsorption, promoting $P$ transfer to surface or subsurface waters. The purpose of this study was to evaluate $P$ accumulation and the pollution potential of a soil after application of pig litter. In March 2010, eight years after the installation of an experiment in Braço do Norte, Santa Catarina, SC, Brazil, on a Typic Hapludult, soil was sampled (layers 0-2.5, 2.5-5, 5-10, 10-15, 15-
\end{abstract}

(1) Part of the Master's Thesis of the first author. Received for publication in May 23, 2011 and approved in June 13, 2012.

(2) Agronomist, Master's Candidate in the Graduate Studies Program in Agroecosystems (PGA) of the Universidade Federal de Santa Catarina (UFSC). Centro de Ciências Agrárias (CCA), Departamento de Engenharia Rural (ENR), UFSC, Itacorubi, CEP 88034-000, Florianópolis (SC), Brazil. Scholarship Holder of CAPES. E-mail: renatoguardini@yahoo.com.br

(3) Agronomist, Doctor in Agronomy, Associate Professor III of the PGA and of the ENR of UFSC. CCA, ENR, UFSC, Itacorubi, CEP 88034-000, Florianópolis (SC), Brazil. E-mail: jcomin@cca.ufsc.br

(4) Agronomist, Doctor in Soil Science, Professor of the Graduate Studies Program in Soil Science (PPGCS) and of the Soil Department (DS) of the Universidade Federal de Santa Maria (UFSM). UFSM, Centro de Ciências Rurais (CCR), DS, Postal Box 221, CEP 97105-900, Santa Maria (RS), Brazil. Scholarship Holder in Productivity of the CNPq. E-mail: danilo.rheinheimer@pq.cnpq.br

(5) Agronomist, Doctor in Agronomy, Associate Professor of the Universidade do Estado de Santa Catarina (UDESC), Av. Luis de Camões, 2090, Lages (SC), Brazil, CEP 88520-000. E-mail: gatiboni@cav.udesc.br

(6) Agronomist, Master in Soil Science, Doctoral Candidate of the PPGCS of the UFSM. UFSM, Centro de Ciências Rurais (CCR), DS, Postal Box 221, CEP 97105-900, Santa Maria (RS), Brazil. Scholarship Holder of Capes. E-mail: tales.t@hotmail.com.

(7) Agronomist, Master's Candidate of the PPGA of UFSC. CCA, ENR, UFSC, Itacorubi, CEP 88034-000, Florianópolis (SC), Brazil. Scholarship Holder of CAPES. E-mail: djalma.schmitt@yahoo.com.br

(8) Student in the Agronomy Course of UFSM. UFSM, Centro de Ciências Rurais (CCR), DS, Postal Box 221, CEP 97105-900, Santa Maria (RS), Brazil. Scholarship Holder in Scientific Initiation. E-mail: marcosantoniobender@yahoo.com.br

(9) Public Health Engineer, Doctor in Industrial and Environmental Chemistry, Assistant Professor in the Public Health and Environmental Engineering Department and in the Graduate Studies Program in Environmental Engineering of UFSC, Trindade, CEP 88040-970, Florianópolis (SC), Brazil. Email: belli@ens.ufsc.br

(10) Agricultural Engineer, Doctor in Environmental Science, Embrapa Suínos e Aves, Postal Box 21, CEP 89700-000, Concórdia (SC), Brazil. E-mail: paolive@cnpsa.embrapa.br

(11) Agronomist, Doctor in Soil Science, Assistant Professor of the PGA and ENR of UFSC. CCA, ENR, UFSC, Itacorubi, CEP 88034-000, Florianópolis (SC), Brazil. E-mail: brunetto.gustavo@gmail.com 
20 and $20-30 \mathrm{~cm}$ ) after the following fertilization treatments: no pig litter fertilization, pig slurry application and pig manure application. In this period, 694 and $1,890 \mathrm{~kg} \mathrm{P}_{2} \mathrm{O}_{5} \mathrm{ha}^{-1}$ were applied in the treatments with pig slurry and pig manure, respectively. The $P$ content was determined, based on Mehlich-1, anion exchange resin (AER), $0.01 \mathrm{~mol} \mathrm{~L}^{-1} \mathrm{CaCl}_{2}$ and total $\mathrm{P}$ in the samples. The adsorption isotherm parameters were also determined by the Langmuir and Koski-Vähälä \& Hartikainem models in the layers 0-2.5 and $20-30 \mathrm{~cm}$. The application of $1,890 \mathrm{~kg}$ $\mathrm{P}_{2} \mathrm{O}_{5} \mathrm{ha}^{-1}$ in the form of pig manure led to $\mathrm{P}$ accumulation, as evidenced by Mehlich1 , down to a depth of $15 \mathrm{~cm}$, by AER and $0.01 \mathrm{~mol} \mathrm{~L}^{-1} \mathrm{CaCl}_{2}$ down to $20 \mathrm{~cm}$ and by total $P$ to $30 \mathrm{~cm}$. After application of $1,890 \mathrm{~kg} \mathrm{P}_{2} \mathrm{O}_{5} \mathrm{ha}^{-1}$ in the form of pig manure, the values of maximum $P$ adsorption capacity were lowest in the deepest layer (20$30 \mathrm{~cm}$ ), indicating the occupation of part of the adsorption sites of the particles. The application of swine manure to the soil over eight years increased the $P$ quantity in the soil solution of the surface layer, indicating environmental contamination risk for surface and subsurface waters.

Index terms: organic fertilization, deep litter, environmental contamination.

\title{
RESUMO: ACÚMULO E POTENCIAL CONTAMINANTE DO FÓSFORO EM UM ARGISSOLO COM APLICAÇÃO DE DEJETOS DE SUÍNOS
}

\begin{abstract}
As aplicações sucessivas de dejetos de suínos na superfície do solo podem aumentar o teor de fósforo $(P)$ e alterar a sua adsorção, potencializando a transferência para as águas superficiais ou subsuperficiais. $O$ presente trabalho objetivou avaliar o acúmulo e o potencial contaminante do P em um solo com aplicação de dejetos de suínos. Em março de 2010, após oito anos da instalação de um experimento localizado no município de Braço do Norte, Santa Catarina (SC), sobre um Argissolo Vermelho, foram coletadas amostras de solo nas camadas de 0-2,5; $2,5-5 ; 5-10 ; 10-15 ; 15-20 ;$ e 20-30 cm, nos tratamentos sem aplicação de dejeto, com aplicação de dejetos líquidos de suínos e com a aplicação de cama sobreposta de suínos. Nesse período, foram aplicados 694 e $1.890 \mathrm{~kg}$ de $\mathrm{P}_{2} \mathrm{O}_{5} \mathrm{ha}^{-1}$ nos tratamentos com dejetos líquidos de suínos e cama sobreposta, respectivamente. Determinou-se o teor de P extraído por Mehlich-1, resina trocadora de ânions (RTA), $\mathrm{CaCl}_{2} 0,01 \mathrm{~mol} \mathrm{~L}^{-1}$ e o $P$ total no solo coletado, bem como foram determinados os parâmetros das isotermas de adsorção pelos modelos de Langmuir e de Koski-Vähälä \& Hartikainem, nas camadas de 0-2,5 e 20-30 cm. A aplicação de $1.890 \mathrm{~kg}$ de $\mathrm{P}_{2} \mathrm{O}_{5} \mathrm{ha}^{-1}$ na forma de cama sobreposta de suínos promoveu o acúmulo de $\mathrm{P}$ extraído por Mehlich-1 até $15 \mathrm{~cm}$ de profundidade, de RTA e CaCl $\mathrm{Cl}_{2} 0,01 \mathrm{~mol} \mathrm{~L}^{-1}$ até $20 \mathrm{~cm}$ e de P total até $30 \mathrm{~cm}$. A adição de $1.890 \mathrm{~kg}$ de $\mathrm{P}_{2} \mathrm{O}_{5} \mathrm{ha}^{-1}$ na forma de cama sobreposta de suínos provocou os menores valores de capacidade máxima de adsorção de P no solo da camada mais profunda (20-30 cm), indicando a ocupação de parte dos sítios de adsorção das partículas. A adição de cama sobreposta de suínos no solo ao longo de oito anos aumentou a quantidade de P na solução na camada superficial do solo, o que significa risco de contaminação ambiental de águas superficiais e subsuperficiais.
\end{abstract}

Termos de indexação: adubação orgânica, cama sobreposta, contaminação ambiental.

\section{INTRODUCTION}

Pig manure can be reused in agricultural establishments as a nutrient source of annual crops and/or pasture. The quantity applied should be determined according to its dry matter percentage, concentration of nutrients $(\mathrm{N}, \mathrm{P}$ and $\mathrm{K})$ and by the efficiency index, which indicates the total nutrient quantity contained in the manure that can be transformed from the organic to the mineral form after soil application (CQFSRS/SC, 2004). Nevertheless, due to the large litter volume produced in relation to the small agricultural areas normally available on swine farms, successive litter applications, in liquid or solid form, occur on the same fields; moreover, the litter is normally applied to the soil surface because of the large extension of soils managed under no-tillage (Ceretta et al., 2003, 2005; Gatiboni et al., 2008). This practice is expected to increase nutrient contents over the years, especially of phosphorus $(\mathrm{P})$, in the soil surface layers (Ceretta et al., 2010a; Girotto et al., 2010).

In the soil, $\mathrm{P}$ derived from pig manure is adsorbed with high binding energy at the surface of the soil mineral fraction. Adsorption occurs mainly through 
the mechanism of ligand exchange, by $\mathrm{OH}^{-}$or $\mathrm{H}_{2} \mathrm{O}$ release and binding of the phosphate ion $\left(\mathrm{H}_{2} \mathrm{PO}_{4}{ }^{-}\right.$or $\mathrm{HPO}_{4}{ }^{-2}$ ) and, depending on the $\mathrm{pH}$ value of the soil, this can occur in the functional groups of oxides and kaolinite. The interaction between the oxygen of the phosphate and the cation of the functional group, especially the aluminol of the clay minerals, and the $\mathrm{Fe}-\mathrm{OH}$ and $\mathrm{Al}-\mathrm{OH}$ groups of the oxide surfaces, results in bonds with different degrees of energy (Barrow, 1998). Thus, it is expected that over the years, continued $\mathrm{P}$ applications to the soil surface can lead to the occupation of the adsorption surfaces, reducing the $\mathrm{P}$ adsorption energy and, consequently, an increase of its desorption and availability (Bolland et al., 1996; Berwanger et al., 2008). The P content, such as that extracted by Mehlich-1, anion exchange resin (AER) and even by $0.01 \mathrm{~mol} \mathrm{~L}^{-1} \mathrm{CaCl}_{2}$, may be used as an indicator of the contamination potential of the soil and water resources, which is already intensely applied in developed countries, especially in the United States (USA) and countries of the European Union (Sharpley \& Halvorson, 1994; Sharpley et al., 1996; Haygarth \& Sharpley, 2000; McDowell \& Sharpley, 2001; McDowell et al., 2002; Fortune et al., 2005), but also in Brazil (Berwanger et al., 2008; Gatiboni et al., 2008).

The maximum $\mathrm{P}$ adsorption capacity in the soil (MPAC) is established by the adsorption isotherms, adjusted by the mathematical model proposed by Langmuir, which relate the sorbed $\mathrm{P}$ and $\mathrm{P}$ in solution (Barrow, 1983; Novais \& Smyth, 1999). With this model, it is possible to observe a reduction in MPAC after $\mathrm{P}$ application, especially in the soil surface layers with a history of application of phosphate fertilizer sources, such as manure (Berwanger et al., 2008; Galvão et al., 2008). The MPAC values depend on the quantity of adsorption sites, defined by the mineralogical composition of the soil, by the specific surface area of the particles and by the crystallinity of the mineral constituents of the soil, as well as by the soil $\mathrm{pH}$ values, the quantity of previously sorbed $\mathrm{P}$ and the presence of organic anions, among other factors of lesser importance (Sposito, 1989; Berwanger et al., 2008). In addition, adjustments of the adsorption isotherm by other models, as that proposed by Koski-Vähälä \& Hartikainem (2001), aggregate the quantity of water-desorbed $\mathrm{P}\left(Q_{o}\right)$, allowing a calculation of the $\mathrm{P}$ concentration required in the solution for half of maximum adsorption $(\mathrm{km})$ and the equilibrium $P$ concentration (ECP) (Koski-Vähälä \& Hartikainem, 2001; Sinaj et al., 2002). This last parameter may be used as an environmental indicator to foresee the possibilities of leaching to subsurface waters and of runoff to surface water bodies (AjmoneMarsan et al., 2006; Gatiboni et al., 2007, 2008; Hao et al., 2008; Chien et al., 2011).

In the south of Brazil, pig slurry is commonly being used as a source of organic fertilizer, but recently the deep-bedding system has become common where pigs are raised in confinement with a layer of organic material, normally wood shavings, crop straw or rice husk, which, among other objectives, has the purpose of reducing dilution of the manure by capturing it in a more solid form which is easier to handle and apply to the soil (Costa et al., 2006). Nevertheless, there is no research information on the impact of this type of material on $\mathrm{P}$ accumulation in the soil and its pollution potential.

The purpose of this study was to evaluate the accumulation and pollution potential of $\mathrm{P}$ in a soil fertilized with pig litter on the surface in the form of pig slurry and manure.

\section{MATERIAL AND METHODS}

\section{Description of the experimental area and treatments}

The experiment was installed on a pig farm in Braço do Norte, southern region of Santa Catarina (SC) (latitude $28^{\circ} 14^{\prime} 20.7$ ', longitude $49^{\circ} 13^{\prime} 55.5^{\prime \prime}$; $300 \mathrm{~m}$ asl), on a Typic Hapludult soil (Embrapa, 2006) with a sandy surface texture, granite substrate and predominance of 1:1 clay (Embrapa, 2004; Uberti, 2005). Prior to the experiment, the soil had the following properties in the $0-10 \mathrm{~cm}$ layer: $330 \mathrm{~g} \mathrm{~kg}^{-1}$ clay; $33 \mathrm{~g} \mathrm{~kg}^{-1}$ organic matter; $\mathrm{pH}$ in water of 5.1 ; SMP Index 5.5; $19 \mathrm{mg} \mathrm{dm}^{-3}$ available $\mathrm{P}$ and $130 \mathrm{mg}$ $\mathrm{dm}^{-3}$ exchangeable K (both extracted by Mehlich-1); $0.8,3.0$ and $0.8 \mathrm{cmol}_{\mathrm{c}} \mathrm{kg}^{-1}$ exchangeable $\mathrm{Al}, \mathrm{Ca}$ and $\mathrm{Mg}$ (extracted by $\mathrm{KCl} 1 \mathrm{~mol} \mathrm{~L}^{-1}$ ). The climate in the region, according to the Köppen-Geiger classification, is humid subtropical (Cfa), with a mean annual temperature of $18.7^{\circ} \mathrm{C}$ and mean annual rainfall of $1,471 \mathrm{~mm}$.

In December 2002, in a pasture area, $6 \mathrm{Mg} \mathrm{ha}^{-1}$ limestone (PRNT $=87.5 \%)$ was applied to the soil surface to raise the water $\mathrm{pH}$ to 6.0 (CFSRS/SC, 1994). In January 2003, the pasture was sprayed and then the following treatments were implemented: control without fertilization and four treatments with pig litter - fertilization with pig slurry (PS) and pig manure (PM), with a normal (PS1, PM1) and double dose (PS2, PM2) of the N recommended for a crop succession of maize (Zea mays) and black oats (Avena strigosa). A randomized block design with three replications was used, with experimental plots of 27 $\mathrm{m}^{2}$ (4.5 m width $\times 6.0 \mathrm{~m}$ length).

For this study, the treatments control, PS1 and PM1 were evaluated. From 2003 to 2010, pig slurry was applied 32 times and pig manure 8 times, equivalent to the application of 694 and $1,890 \mathrm{~kg} \mathrm{P}_{2} \mathrm{O}_{5} \mathrm{ha}^{-1}$, respectively. In the period from 2003 to 2010 , maize (Zea mays) was grown in the summer and black oats (Avena strigosa) in the winter, in succession in a notill system (SPD). The pig slurry dose was applied in rates, with the first application at the time of planting, the second 14 days after crop emergence, the third 30 
days after the second application, and the last before oat planting. Swine manure however was applied only once before planting maize.

\section{Soil collection and analysis of physical and chemical properties}

In March 2010, 88 months after implementation of the experiment, a trench was opened in the center of each plot and soil collected from the layers $0-2.5$, $2.5-5,5-10,10-15,15-20$ and $20-30 \mathrm{~cm}$. This soil was dried in a forced-air laboratory oven at $65{ }^{\circ} \mathrm{C}$ to constant weight. The samples were ground, sieved ( 2 $\mathrm{mm}$ ) and stored.

The particle-size distribution of the soil constituents was determined by the pipette method (Embrapa, 1997). The values of $\mathrm{pH}$ in water (1:1), contents of exchangeable $\mathrm{Al}, \mathrm{Ca}$ and $\mathrm{Mg}\left(1 \mathrm{~mol} \mathrm{~L}^{-1}\right.$ $\mathrm{KCl}$ ), and available $\mathrm{P}$ and exchangeable $\mathrm{K}$ (Mehlich1) were determined as proposed by Tedesco et al. (1995). The AER-extracted $\mathrm{P}$ was determined as described by Gatiboni (2003). P extracted by $0.01 \mathrm{~mol} \mathrm{~L}^{-1} \mathrm{CaCl}_{2}$ and the total $\mathrm{P}$ were determined according to the procedure described by Kuo (1996). Total organic carbon (TOC) was determined as described by Embrapa (1999). The $\mathrm{H}+\mathrm{Al}$, cation exchange capacity $\left(\mathrm{CEC}_{\mathrm{pH} 7.0}\right.$ and $\left.\mathrm{CTC}_{\text {effective }}\right)$, saturation of $\mathrm{CEC}_{\mathrm{pH} 7.0}$ by bases (V \%), and saturation of $\mathrm{CEC}_{\text {effective }}$ by aluminum (m \%) were calculated according to CQFSRS/SC (2004) (Table 1).

\section{Parameters related to adsorption isotherm}

Samples from the 0-2.5 and $20-30 \mathrm{~cm}$ soil layers were subjected to determination of the adsorption isotherm parameters. Therefore, $1.0 \mathrm{~g}$ of dry soil was filled into $15 \mathrm{~mL}$ Falcon tubes. Then, $10 \mathrm{~mL}$ of $0.001 \mathrm{~mol} \mathrm{~L}^{-1} \mathrm{CaCl}_{2}$ solution was added, at $10 \mathrm{P}$ concentrations $(0,0.5,1,2,5,10,20,50,100$ and 400 $\mathrm{mg} \mathrm{L}^{-1}$ ), equivalent to $0,5,10,20,50,100,200,500$, 1000 and $4000 \mathrm{mg} \mathrm{kg}^{-1}$ of $\mathrm{P}$ in the soil, respectively. Thereafter, the tubes were continuously agitated for $16 \mathrm{~h}$ in an end-over-end shaker at $33 \mathrm{rpm}$ and \pm $25{ }^{\circ} \mathrm{C}$. The samples were then centrifuged at $1,350 \mathrm{~g}$ for $10 \mathrm{~min}$ and, in the extractant, the $\mathrm{P}$ remaining content in the solution was determined by the method of Murphy \& Riley (1962). The sorbed P was estimated by the difference between the quantity added and the quantity recovered in the equilibrium solution. Then the data were adjusted by the mathematical model of Langmuir of an adsorption site (Equation 1), described by Barrow (1983):

$$
P_{\text {sorbed }}=\left(k M P A C^{*} P_{\text {solution }}\right) /\left(1+k P_{\text {solution }}\right)
$$

where: $M P A C$ is the maximum $\mathrm{P}$ adsorption capacity; $k$ is a constant which provides information on the affinity of the adsorbate to the substrate surface, and $P_{\text {solution }}$ is the $\mathrm{P}$ concentration in the equilibrium solution.

The equilibrium $\mathrm{P}$ concentration (ECP) was obtained by adjusting the data by the mathematical

Table 1. Physical and chemical properties of a Typic Hapludult soil without pig litter, with the application of pig slurry (PS1) and of pig manure (PM1) in a no-till system

\begin{tabular}{|c|c|c|c|c|c|c|c|c|c|c|c|c|c|c|c|}
\hline Treatment & Layer & Clay $^{(1)}$ & Sand $^{(1)}$ & Silt $^{(1)}$ & TOC $^{(2)}$ & pH- $\mathrm{H}_{2} \mathrm{O}^{(3)}$ & 3) $\mathbf{K}^{(4)}$ & $\mathbf{V}$ & $\mathbf{m}$ & $\mathbf{A l}^{(5)}$ & $\mathbf{C a}^{(5)}$ & $\mathbf{M g}{ }^{(5)}$ & $\mathbf{H}+\mathbf{A l}$ & $\mathrm{CEC}_{\mathrm{pH} 7.0}$ & CEC $_{\text {effect-tive }}$ \\
\hline \multirow{10}{*}{ Control } & $\mathrm{cm}$ & 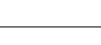 & $\mathrm{g} \mathrm{kg}^{-1}$ & & & $1: 1 \quad n$ & $\mathrm{mg} \mathrm{kg}^{-1}$ & 1 & $\%$ & 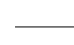 & & $\mathrm{cm}$ & $\mathrm{l}_{\mathrm{c}} \mathrm{kg}^{-1}$ & & \\
\hline & $0-2.5$ & 179 & 628 & 193 & 33.2 & 6.4 & 450 & 86.9 & 0.0 & 0.0 & 10.5 & 4.3 & 2.1 & 18.1 & 15.9 \\
\hline & $2.5-5$ & 204 & 678 & 183 & 26.4 & 6.3 & 562 & 83.0 & 0.0 & 0.0 & 7.9 & 2.3 & 2.2 & 14.1 & 11.8 \\
\hline & $5-10$ & 239 & 593 & 167 & 19.2 & 6.1 & 330 & 74.0 & 0.0 & 0.0 & 4.9 & 1.2 & 2.5 & 9.6 & 7.0 \\
\hline & $10-15$ & 202 & 597 & 242 & 17.6 & 5.9 & 316 & 66.0 & 0.0 & 0.0 & 3.9 & 0.9 & 2.9 & 8.6 & 5.7 \\
\hline & $15-20$ & 245 & 587 & 169 & 15.1 & 5.5 & 240 & 55.5 & 0.0 & 0.0 & 3.1 & 0.7 & 3.5 & 8.0 & 4.4 \\
\hline & $20-30$ & 243 & 574 & 183 & 11.5 & 5.1 & 345 & 38.1 & 13.1 & 0.4 & 1.7 & 0.3 & 4.9 & 8.0 & 3.4 \\
\hline & $0-2.5$ & 197 & 617 & 187 & 34.7 & 6.2 & 518 & 85.4 & 0.0 & 0.0 & 8.3 & 3.4 & 2.2 & 15.3 & 13.1 \\
\hline & $2.5-5$ & 178 & 617 & 204 & 24.4 & 6.2 & $333 \varepsilon$ & 80.6 & 0.0 & 0.0 & 6.5 & 2.2 & 2.2 & 11.9 & 9.6 \\
\hline & $5-10$ & 223 & 604 & 172 & 18.5 & 6.1 & 384 & 78.8 & 0.0 & 0.0 & 5.8 & 2.0 & 2.1 & 11.1 & 8.9 \\
\hline \multirow[t]{3}{*}{ PS1 } & $10-15$ & 208 & 619 & 173 & 14.3 & 5.8 & 263 & 66.4 & 0.0 & 0.0 & 3.9 & 0.9 & 2.8 & 8.3 & 5.5 \\
\hline & $15-20$ & 218 & 611 & 171 & 13.2 & 5.1 & 247 & 45.4 & 12.1 & 0.4 & 1.8 & 0.6 & 3.9 & 8.3 & 3.5 \\
\hline & $20-30$ & 241 & 577 & 182 & 10.9 & 5.1 & 233 & 40.4 & 12.8 & 0.4 & 2.5 & 0.3 & 4.8 & 7.1 & 3.9 \\
\hline \multirow{6}{*}{ PM1 } & $0-2.5$ & 174 & 600 & 226 & 42.2 & 6.3 & 778 & 87.8 & 0.0 & 0.0 & 11.3 & 4.2 & 2.4 & 19.9 & 17.5 \\
\hline & $2.5-5$ & 195 & 577 & 229 & 32.6 & 6.2 & 607 & 85.4 & 0.0 & 0.0 & 10.2 & 3.7 & 2.5 & 18.0 & 15.5 \\
\hline & $5-10$ & 199 & 594 & 207 & 25.6 & 6.2 & 508 & 80.0 & 0.0 & 0.0 & 6.6 & 1.8 & 2.3 & 12.1 & 9.7 \\
\hline & $10-15$ & 238 & 580 & 183 & 15.5 & 6.1 & 458 & 73.1 & 0.0 & 0.0 & 4.6 & 1.4 & 2.6 & 9.8 & 7.2 \\
\hline & $15-20$ & 259 & 596 & 145 & 13.7 & 5.6 & 386 & 54.1 & 0.0 & 0.0 & 2.3 & 0.4 & 3.2 & 7.0 & 3.8 \\
\hline & $20-30$ & 259 & 587 & 154 & 11.5 & 5.1 & 339 & 36.6 & 25.5 & 0.7 & 1.3 & 0.12 & 4.0 & 6.3 & 3.0 \\
\hline
\end{tabular}

(1) Pipette method (Embrapa, 1997); ${ }^{(2)}$ Determined according to Embrapa (1999); (3) Determined according to Tedesco et al. (1995);

(4) Extracted by Mehlich 1 (Tedesco et al., 1995); ${ }^{(5)}$ Extracted by KCl 1 mol L-1 (Tedesco et al., 1995). 
model proposed by Koski-Vähälä \& Hartikainem (2001). These authors introduced the quantity of $P$ desorbed in distilled water $\left(Q_{o}\right)$, which is visually represented by the intersection point on the $y$ axis and the ECP by the intersection on the $x$ axis (Equation 2):

$$
P_{\text {sorbed }}=\left(M P A C * P_{\text {solution }}\right) /\left(k m+P_{\text {solution }}\right)-Q o
$$

where: $M P A C$ is the maximum $\mathrm{P}$ adsorption capacity, $P_{\text {solution }}$ is the $\mathrm{P}$ concentration in the equilibrium solution, $Q_{o}$ is the quantity of $\mathrm{P}$ desorbed in water and $k m$ is the $\mathrm{P}$ concentration in the solution which allows half of the maximum $\mathrm{P}$ adsorption.

\section{Statistical analysis}

A two-factor statistical model was adopted with randomized blocks and subdivided plots with three replications. The manure sources represented the main plots and the soil sampled layers the subplots. The data were subjected to analysis of variance and when significant effects were detected, the mean values were subjected to Tukey's mean comparison test $(\alpha=5 \%)$.

\section{RESULTS AND DISCUSSION}

The soil of the $0-2.5 \mathrm{~cm}$ layer in the control treatment contained $92.1,61.7,4.25$ and $657.3 \mathrm{mg}$ $\mathrm{kg}^{-1} \mathrm{P}$ extracted by Mehlich-1, AER, $0.01 \mathrm{~mol} \mathrm{~L}^{-1}$ $\mathrm{CaCl}_{2}$ and total $\mathrm{P}$, respectively, while with the application of $1,890 \mathrm{~kg} \mathrm{P}_{2} \mathrm{O}_{5} \mathrm{ha}^{-1}$ in the form of pig manure (PM1), the contents increased to 606.4, 351.1, 24.56 , and $1912.4 \mathrm{mg} \mathrm{kg}^{-1}$, respectively (Figures 1a, $\mathrm{b}, \mathrm{c}, \mathrm{d})$. With the application of $694 \mathrm{~kg} \mathrm{P}_{2} \mathrm{O}_{5} \mathrm{ha}^{-1}$ in the form of pig slurry (PS1), on the other hand, the $\mathrm{P}$ contents extracted by Mehlich-1, AER, $0.01 \mathrm{~mol} \mathrm{~L}^{-1}$ $\mathrm{CaCl}_{2}$, and total $\mathrm{P}$ were $207.6,165.2,12.11$, and 928.2 $\mathrm{mg} \mathrm{kg}^{-1}$, respectively (Figures 1a, b, c, d). This shows that the application of litter to the soil surface without tillage increased the $\mathrm{P}$ content in the surface layer over the years, in agreement with the data obtained by Gatiboni et al. (2007, 2008) and Ceretta et al. (2010a). These authors also reported that part of the $\mathrm{P}$ applied, regardless of its origin, accumulates preferentially in organic forms in the soil, and can be bioavailable to crops (Santos et al., 2008; Pavinato et al., 2009), but increases potential losses through surface runoff (Ajmone-Marsan et al., 2006; Gatiboni et al., 2007; Hao et al., 2008; Ceretta et al., 2010b; Chien et al., 2011). The low $\mathrm{P}$ export in maize grain, harvested only once a year, together with low rates of soil loss because of adoption of the no-till system may also have contributed to $\mathrm{P}$ accumulation, detected by different extractants (Figures 1a, b, c, d), in the soil surface layer, which agrees with the data obtained by Durigon et al. (2002) and Ceretta et al. (2003) in natural pastures with a history of application of pig litter and low $\mathrm{P}$ export.
Higher Mehlich-1-extracted $\mathrm{P}$ contents were detected down to a depth of $15 \mathrm{~cm}$ in the PM1 than in the control treatment, which was not fertilized with pig litter throughout the experiment (Figure 1a). The P contents determined by Mehlich-1 in the 0-2.5, 2.5$5.0,5-10$, and $10-15 \mathrm{~cm}$ soil layers in the PM1 treatment were $606.4,385.5,253.1$ and $129.0 \mathrm{mg} \mathrm{kg}^{-1}$, respectively. The Soil Chemistry and Fertility Commission of the States of RS and SC (CQFSRS/SC, 2004) suggested that the $P$ contents extracted by Mehlich-1, in soils with 210 to $400 \mathrm{~g} \mathrm{~kg}^{-1}$ clay and in the $0-10 \mathrm{~cm}$ layer in the no-till system, should not be greater than $24 \mathrm{mg} \mathrm{kg}^{-1}$ because of environmental risks, which are interpreted as "very high". In the USA, Sharpley et al. (1996) report that Mehlich-1-extracted $P$ contents of $120 \mathrm{mg} \mathrm{kg}^{-1}$ are considered critical in the soil; the application of organic or mineral fertilizers is not recommended in this situation, with a view to a reduction of the soil contents in the long term.

The highest $\mathrm{P}$ contents extracted by AER were down found to a depth of $20 \mathrm{~cm}$ in the PM1 treatment, compared with the control (Figure $1 \mathrm{~b}$ ). The contents of $\mathrm{P}$ detected by AER in the 0-2.5, 2.5-5, 5-10, 10-15, and 15-20 cm soil layers in the PM1 treatment were $351.1,307.2,219.3,127.9$, and $63.9 \mathrm{mg} \mathrm{kg}^{-1}$, respectively. After the application of $1,890 \mathrm{~kg}$ $\mathrm{P}_{2} \mathrm{O}_{5} \mathrm{ha}^{-1}$ in $\mathrm{PM} 1$, the mean $\mathrm{P}$ content extracted by AER from the 0-2.5, 2.5-5 and 5-10 cm layers was $114 \mathrm{mg} \mathrm{kg}^{-1}$, which is considered very high $(>40 \mathrm{mg}$ $\mathrm{kg}^{-1}$ ) for the $0-10 \mathrm{~cm}$ layer in a no-tillage system (CQFSRS/SC, 2004), which consequently increases the potential for environmental contamination.

The highest $\mathrm{P}$ contents extracted by $0.01 \mathrm{~mol} \mathrm{~L}^{-1}$ $\mathrm{CaCl}_{2}$ were found down to a depth of $20 \mathrm{~cm}$ depth in the PM1 treatment, compared with the control (Figure 1c), which agrees with the data obtained by AER. The contents of $\mathrm{P}$ extracted by $0.01 \mathrm{~mol} \mathrm{~L}^{-1} \mathrm{CaCl}_{2}$ in the 0 $2.5,2.5-5,5-10,10-15$, and $15-20 \mathrm{~cm}$ soil layers in the PM1 treatment were 24.5, 21.1, 12.9, 4.2 and $2.4 \mathrm{mg}$ $\mathrm{kg}^{-1}$, respectively. The contents of $0.01 \mathrm{~mol} \mathrm{~L}^{-1} \mathrm{CaCl}_{2}$ were similar to those found in solution, e.g., in the leachate, and can also be used as an indication of environmental contamination (McDowell \& Sharpley, 2001; McDowell et al., 2002). On the other hand, the total soil P contents were also highest in the PM1 treatment down to a depth of $30 \mathrm{~cm}$ (Figure 1d). The total $P$ contents in the $0-2.5,2.5-5,5-10,10-15,15-20$, and 20-30 cm soil layers of the PM1 treatment were $1912.4,1641.8,1122.3,738,522.8$, and $358.6 \mathrm{mg} \mathrm{kg}^{-1}$, respectively.

The application of 694 and $1,890 \mathrm{~kg} \mathrm{P}_{2} \mathrm{O}_{5} \mathrm{ha}^{-1}$ to the soil in the PS1 and PM1 treatments, respectively, and the adsorption of part of this $\mathrm{P}$ by the functional groups of the reactive particles, altered the curvature of the $\mathrm{P}$ adsorption isotherm in the soil in the $0-2.5$ and $20-30 \mathrm{~cm}$ layers compared with the control treatment (Figure 2).

The maximum phosphorus adsorption capacity (MPAC), a parameter adjusted by the Langmuir equation, in the $0-2.5 \mathrm{~cm}$ layer of the control, PS1 

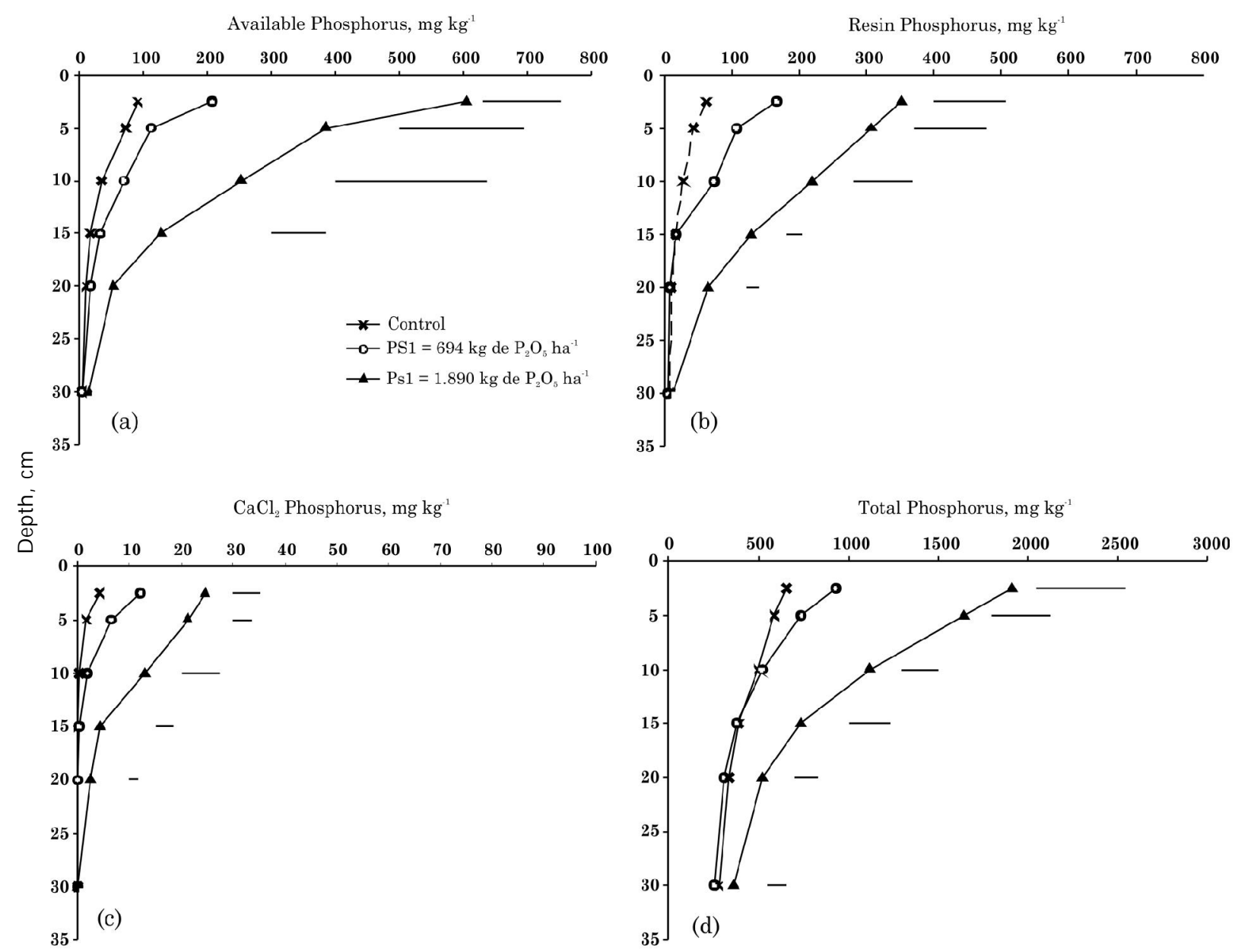

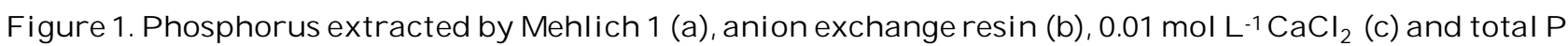
(d) throughout the profile of a Typic Hapludult soil without the pig litter fertlization, with the application of pig slurry (PS1) and of pig manure (PM1) in a no-till system. The horizontal bars indicate minimum significant difference by the Tukey test at $5 \%$.

and PM1 treatments, were 367, 363 and $426 \mathrm{mg} \mathrm{kg}^{-1}$, respectively, and were not statistically different (Table 2 ). The MPAC values obtained in the $0-2.5 \mathrm{~cm}$ layer were similar to those reported by Berwanger et al. (2008), also in a Hapludult soil with a history of pig slurry application in a no-till system. These MPAC values are justified by this soil type, which has a low quantity of phosphate adsorption sites (Rheinheimer et al., 2003) due to the low clay contents (Table 1), and the presence of 1:1 type clay minerals (Embrapa, 2004; Uberti 2005) and negligible quantities of oxides (Gatiboni et al., 2008; Ceretta et al., 2010a).

On the other hand, the MPAC values in the 20-30 cm layer in the same control, PS1 and PM1 treatments were 995, 875 and $701 \mathrm{mg} \mathrm{kg}^{-1}$, respectively (Table 2). The lower MPAC values in the soil subjected to the application of PM1 may be attributed to the history of $\mathrm{P}$ application, which favored the occupation of $\mathrm{P}$ adsorption sites, especially those located in inorganic reactive soil particles (Berwanger etal., 2008). However, it should be emphasized that the lowest value of MPAC found in the $20-30 \mathrm{~cm}$ layer in the PM1 treatment may also be related to a greater adsorption of organic ligands at the $\mathrm{P}$ adsorption sites derived from the decomposition of the applied organic residues (Jara et al., 2006; Ashworth \& Alloway, 2008; Zhang \& Zhang., 2010).

The reduction in MPAC in the PM1 treatment in the 20-30 cm layer indicated $P$ migration down to this soil depth, partially occupying the adsorption sites. This effect was detected by the analysis of total $\mathrm{P}$ (Figure 1d), but not by the $\mathrm{P}$ extractants Mehlich-1, AER and $0.01 \mathrm{~mol} \mathrm{~L}^{-1} \mathrm{CaCl}_{2}$ (Figures $1 \mathrm{a}, \mathrm{b}, \mathrm{c}, \mathrm{d}$ ). Nevertheless, it should be noted that part of the $P$ might not have migrated into the soil profile but may rather have been transferred by surface runoff, which is common on soils under no-tillage with a history of pig litter application and $\mathrm{P}$ accumulation in the surface layer (Ceretta et al., 2010b). 

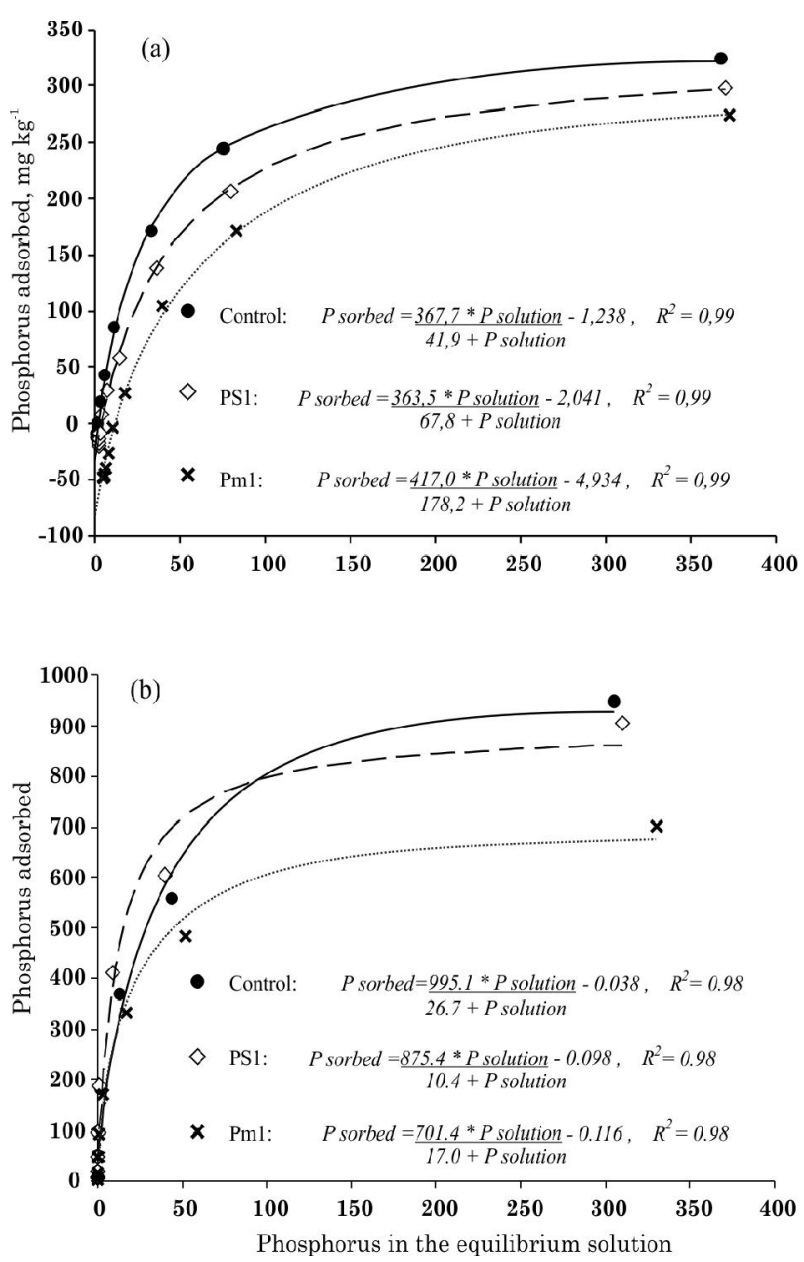

Figure 2. Ratio between the $P$ adsorbed and the $P$ in equilibrium solution of the soil in the $0-2.5 \mathrm{~cm}$ (a) and 20-30 cm (b) layers in a Typic Hapludult soil without pig litter fertilization, with the application of pig slurry (PS1) and of pig manure (PM1) in a no-till system.

The lower MPAC values in the $0-2.5 \mathrm{~cm}$ than in the 20-30 soil $\mathrm{cm}$ layer, in all treatments, can be explained by the greater organic $\mathrm{C}$ contents and consequently of organic matter in the soil (Table 1). This is particularly true for the PS1 and PM1 soils, where the addition of phosphate via litter caused occupation of the adsorption sites in the long term and changed the physical and chemical performance of the inorganic colloids (Parfitt, 1978; Barrow et al., 1998; Berwanger et al., 2008; Ceretta et al., 2010a). Another factor that contributed to this pattern was the greater clay content in the $20-30 \mathrm{~cm}$ than in the surface layer (Table 1), resulting in the highest MPAC in the deepest layer in all treatments, including the control.

The values of the constant related to affinity of the adsorbate on the substrate surface $(k)$ in the $0-2.5 \mathrm{~cm}$ layer tended to be greater in the control treatment (0.0250 $\left.\mathrm{mg} \mathrm{L}^{-1}\right)$ and PS1 (0.0147 $\left.\mathrm{mg} \mathrm{L}^{-1}\right)$ compared to the PM1 soil (0.0056 $\mathrm{mg} \mathrm{L}^{-1}$ ) (Table 2). In the 20-30 $\mathrm{cm}$ soil layer of the control, PS1 and PM1 treatments, the $k$ values were $0.0481,0.1053$ and $0.0612 \mathrm{mg} \mathrm{L}^{-1}$, respectively. It should be noted that the lower $k$ values, the mean of the control, PS1 and PM1 treatments in the 0-2.5 cm layer in comparison to those obtained in the $20-30 \mathrm{~cm}$ layer could be associated with the occupation of the adsorption sites of the reactive soil particles by phosphate (Bolland et al., 1996; Berwanger et al., 2008) and, moreover, the greater mean $k$ values in the deepest layer indicate the greater avidity of the adsorption sites for $\mathrm{P}$ in that layer, given that a smaller quantity of P migrated to the subsurface layer. In the adsorption isotherm parameters adjusted by the equation proposed by Koski-Vähälä \& Hartikainem (2001), the MPAC contents in the 0-2.5 $\mathrm{cm}$ soil layer were 368,364 and $417 \mathrm{mg} \mathrm{kg}^{-1}$ in the control, PS1 and PM1, respectively, practically identical to those obtained with the Langmuir model (Table 2). The greatest $P$ concentration in the solution that allows half of maximum $\mathrm{P}$ adsorption $(\mathrm{km})$, of $\mathrm{P}$ desorbed in water $(Q o)$ and of equilibrium $\mathrm{P}$ concentration (ECP) in the soil of the $0-2.5 \mathrm{~cm}$ layer was obtained in the PM1 treatment in comparison to the control and PS1. These results are related to the greater addition of $\mathrm{P}$ and to the $\mathrm{P}$ content extracted by Mehlich-1, AER, $0.01 \mathrm{~mol} \mathrm{~L}^{-1} \mathrm{CaCl}_{2}$ and total $\mathrm{P}$ (Figures $1 \mathrm{a}, \mathrm{b}, \mathrm{c}, \mathrm{d}$ ) in the $0-2.5 \mathrm{~cm}$ soil layer in the PM1 treatment, which was greater than in the control and PS1 treatments. On the other hand, in the 20-30 $\mathrm{cm}$ layer, the lowest MPAC values were found in the PM1 treatment, corroborating the MPAC values obtained with the Langmuir model (Table 2). In this same soil layer, the values of $k m, Q o$ and ECP did not differ among the control, PS1 and PM1 treatments, with a lower $\mathrm{P}$ desorption capacity. The ECP is a theoretical parameter important in the study of soil pollution potential because this value indicates that, in the case of P-rich soil transfer (sediment) through erosion to an aquatic environment, there will be the potential for release of the element to the water whenever the water soluble $\mathrm{P}$ content of the aquatic environment is lower than the ECP. Thus, for a sediment originating from the surface layer of the soil fertilized with swine manure, if the water source has a value $<2.41 \mathrm{mg} \mathrm{L}^{-1}$, the sediment will be a source of $\mathrm{P}$ to contaminate the system; on the other hand, from the soil of the $20-30 \mathrm{~cm}$ layer, also fertilized with swine manure, the release of $\mathrm{P}$ to the water will cease when the water body has a soluble P content $>0.002 \mathrm{mg} \mathrm{L}^{-1}$, i.e., a much lower pollution potential than the soil with the low ECP value. Thus, the $\mathrm{P}$ found in the soil of the $0-2.5 \mathrm{~cm}$ layer in the PM1 treatment could be more polluting than in the other treatments, and might cause contamination of surface and/or subsurface waters (Berwanger et al., 2008; Gatiboni et al., 2008).

In the 20-30 cm soil layer, the MPAC values in the control, PS1 and PM1 treatments were greater than those in the $0-2.5 \mathrm{~cm}$ layer, in agreement with 
Table 2. Parameters related to the adsorption isotherms in the 0-2.5 and 20-30 cm layers of a Typic Hapludult soil without pig litter fertilization, with the application of pig slurry (PS1) and of pig manure (PM1) in a no-till system

\begin{tabular}{|c|c|c|c|c|c|c|c|}
\hline \multirow[t]{2}{*}{$\begin{array}{l}\text { Source of } \\
\text { pig litter }\end{array}$} & \multirow[t]{2}{*}{$\begin{array}{l}\text { Total } \mathbf{P} \\
\text { applied }\end{array}$} & \multicolumn{2}{|c|}{$\begin{array}{l}\text { Parameters adjusted } \\
\text { by the Langmuir equation }\end{array}$} & \multicolumn{4}{|c|}{$\begin{array}{c}\text { Parameters adjusted by the } \\
\text { Koski-Vähälä \& Hartikainem equation }\end{array}$} \\
\hline & & $\operatorname{MPAC}^{(1)}$ & $k^{(2)}$ & MPAC & $k m^{(3)}$ & $Q o^{(4)}$ & $\mathrm{ECP}^{(5)}$ \\
\hline & $\mathrm{kg} \mathrm{ha}^{-1}$ & $\mathrm{mg} \mathrm{kg}^{-1}$ & $\mathrm{~L} \mathrm{mg}^{-1}$ & $\mathrm{mg} \mathrm{kg}^{-1}$ & & $-\mathrm{mg} \mathrm{L}^{-1}$ & \\
\hline & & \multicolumn{6}{|c|}{$0-2.5 \mathrm{~cm}$} \\
\hline Control & 0 & $367 \mathrm{aB}^{(6)}$ & 0.0250 & $368 \mathrm{aB}$ & $41.9 \mathrm{bA}$ & $1.238 \mathrm{bA}$ & $0.14818 \mathrm{bA}$ \\
\hline PS1 & 694 & $363 \mathrm{aB}$ & 0.0147 & $364 \mathrm{aB}$ & $67.8 \mathrm{bA}$ & $2.041 \mathrm{bA}$ & $0.38572 \mathrm{bA}$ \\
\hline PM1 & 1890 & $426 \mathrm{aB}$ & 0.0056 & $417 \mathrm{aB}$ & $178.2 \mathrm{aA}$ & $4.934 \mathrm{aA}$ & $2.41591 \mathrm{aA}$ \\
\hline \multirow[t]{2}{*}{ Mean } & - & - & $0.0151 \mathrm{~b}$ & - & - & - & - \\
\hline & & \multicolumn{6}{|c|}{$20-30 \mathrm{~cm}$} \\
\hline Control & 0 & $995 \mathrm{aA}$ & 0.0481 & $995 \mathrm{aA}$ & $26.7 \mathrm{aA}$ & $0.038 \mathrm{aA}$ & $0.00093 \mathrm{aA}$ \\
\hline PS1 & 694 & 875 abA & 0.1053 & $875 \mathrm{abA}$ & $10.4 \mathrm{aA}$ & $0.098 \mathrm{aB}$ & $0.00113 \mathrm{aB}$ \\
\hline PM1 & 1890 & $701 \mathrm{bA}$ & 0.0612 & $701 \mathrm{bA}$ & $17.0 \mathrm{aB}$ & $0.116 \mathrm{aB}$ & $0.00286 \mathrm{aB}$ \\
\hline Mean & - & - & $0.0715 \mathrm{a}$ & & - & - & - \\
\hline $\mathrm{CV} \%$ & - & 8.16 & 44.95 & 8.62 & 55.68 & 52.84 & 58.34 \\
\hline
\end{tabular}

(1) Maximum $\mathrm{P}$ adsorption capacity. ${ }^{(2)}$ Constant that can provide information regarding the affinity of the adsorbate for the surface of the substrate. ${ }^{(3)} \mathrm{P}$ concentration in the solution that allows half of maximum $\mathrm{P}$ adsorption. ${ }^{(4)}$ Quantity of $\mathrm{P}$ desorbed with water. ${ }^{(5)}$ Equilibrium P concentration. ${ }^{(6)}$ Means followed by the same small letter in the column and at the same depth, and capital letters in the same treatment, but among the different depths, do not differ from each other by the Tukey test at $5 \%$.

the MPAC values obtained through the Langmuir model, indicating that the colloids found in this layer are more avid in adsorbing the phosphate (Table 2). That could be one of the possible explanations for the lower values of $\mathrm{km}$ in the soil of the PM1 treatment and of $Q o$ and ECP in the PM1 and PS1 treatments in comparison to the values obtained in the $0-2.5 \mathrm{~cm}$ layer. Thus, the strategy of sporadically tilling soils with a history of litter application and $\mathrm{P}$ accumulation on the surface layer of the soil through plowing and/ or disking over the years would be adequate since it would increase phosphate adsorption by the functional groups of the reactive particles found in the deeper soil layers. Thus, $\mathrm{P}$ transfer to the environment would tend to be reduced as a result of the lower concentrations of the element in solution (KoskiVähälä \& Hartikainem, 2001; Sinaj et al., 2002). Nevertheless, it should also be noted that other practices, such as reducing the frequency of pig litter application over years to crops could be another suitable practice to decrease the $\mathrm{P}$ contents in the soil profile, minimizing environmental contamination.

\section{CONCLUSIONS}

1. The application of $1,890 \mathrm{~kg} \mathrm{P}_{2} \mathrm{O}_{5} \mathrm{ha}^{-1}$ in the form of swine manure led to an accumulation of Mehlich-1-extracted $\mathrm{P}$ down to a depth of $15 \mathrm{~cm}$, by anion exchange resin and $0.01 \mathrm{~mol} \mathrm{~L}^{-1} \mathrm{CaCl}_{2}$ down to $20 \mathrm{~cm}$, and by total $\mathrm{P}$ to $30 \mathrm{~cm}$.
2. The maximum $P$ adsorption capacity was lowest after the application of $1,890 \mathrm{~kg} \mathrm{P}_{2} \mathrm{O}_{5} \mathrm{ha}^{-1}$ in the form of swine manure in the $20-30 \mathrm{~cm}$ soil layer, indicating occupation of part of the particle adsorption sites.

3 . The application of swine manure to the soil over eight years increased the $\mathrm{P}$ quantity in the soil solution of the surface layer, indicating environmental contamination risks of surface and subsurface waters.

\section{ACKNOWLEDGEMENTS}

The authors are indebted to the Tecnologias Sociais para a Gestão da Água (TSGA) Project, Fundação de Pesquisa de Santa Catarina (FAPESC) and the Conselho Nacional de Desenvolvimento Científico e Tecnológico $(\mathrm{CNPq})$ for financial support, the Coordenação de Aperfeiçoamento de Pessoal de Nível Superior (CAPES) for the master scholarship of the first and sixth author, as well as to the CNPq for the Scientific Initiation scholarship Pibic/CNPq of the seventh author.

\section{LITERATURE CITED}

AJMONE-MARSAN, F.; CÔTÉ, D. \& SIMARD, R.R. Phosphorus transformations under reduction in longterm manure soils. Plant Soil, 282:239-250, 2006. 
ASHWORTH, D.J. \& ALLOWAY, B.J. Influence of dissolved organic matter on the solubility of heavy metals in sewagesludge amended soils. Comm. Soil Sci. Plant Anal., 39:538$550,2008$.

BARROW, N.J. A mechanistic model for describing the sorption and desorption of phosphate by soil. J. Soil Sci., 34:733$750,1983$.

BARROW, N.J.; BOLLAND, M.D.A. \& ALLEN, D.G. Effect of addition of superphosphate on sorption of phosphate. Austr. J. Soil Res., 36:359-372, 1998.

BERWANGER, A.L.; CERETTA, C.A. \& RHEINHEIMER, D.S. Alterações no teor de fósforo no solo com aplicação de dejetos líquidos de suínos. R. Bras. Ci. Solo, 32:2525-2532, 2008.

BOLLAND, M.D.A.; GILKES, R.J.; BRENNAN, R.F. \& ALLEN, D.G. Comparison of seven phosphorus sorption indices. Austr. J. Soil Res., 34:81-89, 1996.

CERETTA, C.A.; BASSO, C.J.; VIEIRA, F.C.B.; HERBES, M.G.; MOREIRA, I.C.L. \& BERWANGER, A.L. Dejeto líquido de suínos: I - perdas de nitrogênio e fósforo na solução escoada na superfície do solo, sob plantio direto. Ci. Rural, 35:1296-1304, 2005.

CERETTA, C.A.; DURIGON, R.; BASSO, C.J.; BARCELLOS, L.A.R. \& VIEIRA, F.C.B. Características químicas de solo sob aplicação de esterco líquido de suínos em pastagem natural. Pesq. Agropec. Bras., 38:729-735, 2003.

CERETTA, C.A.; GIROTTO, E.; LOURENZI, C.R.; TRENTIN, G.; VIEIRA, R.C.B. \& BRUNETTO, G. Nutrient transfer by runoff under no tillage in a soil treated with successive applications of pig slurry. Agric. Ecosyst. Environ., 139:689-699, 2010b.

CERETTA, C.A.; LORENSINI, F.; BRUNETTO, G.; GIROTTO, E.; GATIBONI, L.C.; LOURENZI, C.R.; TIECHER, T.L.; DE CONTI, L.; TRENTIN, G. \& MIOTTO, A. Frações de fósforo no solo após sucessivas aplicações de dejetos de suínos em plantio direto. Pesq. Agropec. Bras., 45:593602, 2010a.

CHIEN, S.H.; PROCHNOW, L.I.; TU, S. \& SNYDER, C.S. Agronomic and environmental aspects of phosphate fertilizers varying in source and solubility: An update review. Nutr. Cycl. Agroecosyst., 89:229-255, 2011.

COMISSÃO DE FERTILIDADE DO SOLO - CFSRS/SC. Recomendação de adubação e calagem para os estados do Rio Grande do Sul e Santa Catarina. 3. ed. Passo Fundo, SBCS/NRS/EMBRAPA/CNPT, 1994. 224p.

COMISSÃO DE QUÍMICA E FERTILIDADE DO SOLO CQFSRS/SC. Manual de adubação e calagem para os estados do Rio Grande do Sul e Santa Catarina. 10. ed. Porto Alegre, 2004. 400p.

COSTA, O.D.; OLIVEIRA, P.A.V.; HOLDEFER, C.; LOPES, E.J.C. \& SANGOI, V. Sistema alternativo de criação de suínos em cama sobreposta para a agricultura familiar. Concórdia, Embrapa, 2006. 7p. (Comunicado Técnico, 419)

DURIGON, R.; CERETTA, C.A.; BASSO, C.J.; BARCELLOS, L.A.R. \& PAVINATO, P.S. Produção de forragem em pastagem natural com o uso de esterco líquido de suíno. R. Bras. Ci. Solo, 22:983-992, 2002.
EMPRESA BRASILEIRA DE PESQUISA AGROPECUÁRIA EMBRAPA. Centro Nacional de Pesquisa do Solo. Manual de métodos de análise de solos. Rio de Janeiro, 1997. 212p.

EMPRESA BRASILEIRA DE PESQUISA AGROPECUÁRIA EMBRAPA. Centro Nacional de Pesquisa do Solo. Sistema brasileiro de classificação de solos. Rio de Janeiro, 2006. 306p.

EMPRESA BRASILEIRA DE PESQUISA AGROPECUÁRIA EMBRAPA. Centro Nacional de Pesquisa do Solo. Solos do Estado de Santa Catarina Rio de Janeiro, Embrapa Solos, 2004. 745p. (Boletim de Desenvolvimento e Pesquisa)

EMPRESA BRASILEIRA DE PESQUISA AGROPECUÁRIA EMBRAPA. Manual de análises químicas de solos, plantas e fertilizantes. Brasília, 1999. 370p.

FORTUNE, S.; LU, J.; ADDISCOTT, T.M. \& BROOKES, P.C. Assessment of phosphorus leaching losses arable land. Plant Soil, 269:99-108, 2005.

GALVÃO, S.R.S.; SALCEDO, I.H. \& OLIVEIRA, F.F. Acumulação de nutrientes em solos arenosos adubados com esterco bovino. Pesq. Agropec. Bras., 43:99 105, 2008.

GATIBONI L.C.; RHEINHEIMER D.S; KAMINSKI J \& FLORES J.P.C. Biodisponibilidade de formas de fósforo acumuladas em solo sob sistema plantio direto. R. Bras. Ci. Solo, 31:691-699, 2007.

GATIBONI, L.C. Disponibilidade de formas de fósforo do solo às plantas. Santa Maria, Universidade Federal de Santa Maria, 2003. 231p. (Tese de Doutorado)

GATIBONI, L.C.; BRUNETTO, G.; KAMINSKI, J.; RHEINHEIMER, D.S.; CERETTA, C.A. \& BASSO, C.J. Formas de fósforo no solo após sucessivas adições de dejeto líquido de suínos em pastagem natural. R. Bras. Ci. Solo, $32: 17531761,2008$.

GIROTTO, E.; CERETTA, C.A.; BRUNETTO, G.; RHEINHEIMER, D.S.; SILVA, L.S.; LOURENSINI, F.; LOURENZI, C.R.; VIEIRA, R.C.B. \& SCHMATZ, R. Acúmulo e formas de cobre e zinco no solo após aplicações sucessivas de dejeto líquido de suínos. R. Bras. Ci. Solo, 34:955-965, 2010.

HAO, X.; GODLINSKI, F. \& CHANG, C. Distribution of phosphorus forms in soil following long-term continuous and discontinuous cattle manure applications. Soil Sci. Soc. Am. J., 72:90-97, 2008.

HAYGARTH, P.M. \& SHARPLEY, A.N. Terminology for phosphorus transfer. J. Environ. Quality., 29:10-15, 2000.

JARA, A.A.; VIOLANTE, A.; PIGNA, M. \& MORA, M.D.L. Mutual interactions of sulfate, oxalate, citrate, and phosphate on synthetic and natural allophanes. Soil Sci. Soc. Am. J., 70:337-346, 2006.

KOSKI-VÄHÄLÄ, J. \& HARTIKAINEN, H. Assessment of the risk of phosphorus loading due to resuspended sediment. J. Environ. Qual., 30:960-966, 2001.

KUO, S. Phosphorus. In: SPARKS, D.L., ed. Methods of soil analysis: Chemical methods. Madison, SSSA, 1996. Part 3. p.869-920. 
McDOWELL, R.W. \& SHARPLEY, A.N. Approximating phosphorus release from soils to surface runoff and subsurface drainage. J. Environ. Qual., 30:508-520, 2001.

McDOWELL, R.W.; CONDRON, L.M.; MAHIEU, N.; BROOKES, P.C.; POULTON, P.R. \& SHARPLEY, A.N. Analysis of potentially mobile phosphorus in arable soils using solid state nuclear magnetic resonance. J. Environ. Qual., 31:450-456, 2002.

MURPHY, J. \& RILEY, J.P. A Modified single solution method for determination of phosphate in natural waters. Anal. Chem. Acta, 27:31-36, 1962.

NOVAIS, R.F. \& SMYTH, T.J. Fósforo em solo e planta em condições tropicais. Viçosa, MG, UFV/DPS, 1999. 399p.

PARFITT, R.L. Anion adsorption by soils and soil materials. Adv. Agron., 30:01-46, 1978.

PAVINATO, P.S; MERLIN, A. \& ROSOLEN, C.A. Phosphorus fractions in Brazilian Cerrado soils as affected by tillage. Soil Tillage Res., 105:149-155, 2009.

RHEINHEIMER, D.S.; ANGHINONI, I. \& CONTE, E. Sorção de Fósforo em função do teor inicial e de sistemas de manejo de solos. R. Bras. Ci. Solo, 27:41-49, 2003.

SANTOS J.Z.L.; FURTINI A.E.N.; RESENDE Á.V.; CURI N.; CARNEIRO L.F. \& COSTA S.E.V.G.A. Frações de fósforo em solo adubado com fosfatos em diferentes modos de aplicação e cultivado com milho. R. Bras. Ci. Solo 32:705714, 2008.
SHARPLEY, A.N. \& HALVORSON, D.A. The management of soil phosphorus availability and its impact on surface water quality. In: LAL, R. \& STEWART, B.A. Soil processes and water quality. Madison, American Society of Agronomy, 1994. p.7-89.

SHARPLEY, A.N.; DANIEL, T.C.; SIMS, J.T. \& POTE, D.H. Determining environmentally sound soil phosphorus levels. J. Soil Water Conserv., 51:160-166, 1996.

SINAJ, S.; STAMM, C.; TOOR, G.S.; CONDRON, L.M.; HENDRY, T.; DI, H.J.; CAMERON, C.K. \& FROSSARD, E. Phosphorus exchangeability and leaching losses from two grassland soils. J. Environ. Qual., 31:319$330,2002$.

SPOSITO, G. The chemistry of soil. New York, Oxford University Press, 1989. 277p.

TEDESCO, M.J.; GIANELLO, C.; BISSANI, C.A.; BOHNEN, H. \& VOLKWEISS, S.J. Análises de solo, planta e outros materiais. 2.ed. Porto Alegre, Universidade Federal do Rio Grande do Sul, 1995. 174p.

UBERTI, A.A.A. Santa Catarina: Proposta de divisão territorial em Regiões edafoclimáticas homogêneas. Florianópolis, Universidade Federal de Santa Catarina, 2005. 185p. (Tese de Doutorado)

ZHANG, M. \& ZHANG, H. Co-transport of dissolved organic matter and heavy metals in soils induced by excessive phosphorus applications. J. Environ. Sci., 22:598-606, 2010 . 